\title{
PENYULUHAN KEWIRAUSAHAAN DAN CARA PENANAMAN PEPAYA CALIFORNIA PADA LAHAN KOSONG UNTUK MENINGKATKAN KESEJAHTERAAN BURUH TANI
}

\author{
Purnadi \\ Universitas Muhammadiyah Purwokerto \\ Hengky Widhiandono \\ Universitas Muhammadiyah Purwokerto
}

Akhmad Darmawan

Universitas Muhammadiyah Purwokerto

\begin{abstract}
Improving the welfare of farm laborers may do with the counseling program and Pepaya california growing practices. This program provides knowledge about business prospect and how to plant Pepaya california by a farmer who have been successful and experienced. There should be proper coordination of all parties to such social programs can be run properly.
\end{abstract}

Keywords: Welfare, Farm Laborers, Counseling Program, Papaya California.

\section{Abstrak}

Peningkatan kesejahteraan buruh tani dapat dilakukan dengan adanya program penyuluhan dan praktik penanaman Pepaya california. Program ini memberikan pengetahuan tentang bisnis Pepaya california serta cara menanamnya oleh petani yang telah berhasil dan berpengalaman. Perlu ada koordinasi yang baik bagi semua pihak agar program pengabdian seperti ini dapat berjalan dengan baik.

Kata kunci: Kesejahteraan, Buruh tani, Penyuluhan, Pepaya California.

\section{PENDAHULUAN}

Secara goografis Desa Gandatapa terletak di wilayah kecamatan Sumbang, Kabupaten Banyumas memiliki iklim yang sejuk karena terletak di kaki Gunung Slamet. Desa Gandatapa berbatasan sebelah timur dengan Desa Sikapat, Selatan dengan Desa Banteran, Barat dengan Desa Kotayasa, dan Utara dengan tanah milik PERHUTANI, sedangkan jarak ke pusat kota Purwokerto sekitar 10 Kilometer.

Berdasarkan hasil (Survei, 2016), sebagaimana umumnya kondisi di desa, Desa Gandatapa memiliki banyak sumberdaya, baik sumberdaya alam maupun sumberdaya manusia yang bisa dikembangkan. Sumberdaya alam yang melimpah pada umumnya merupakan hasil pertanian seperti: dilem, padi, palawija, timun, terong, lombok, cabe, buncis. Sedangkan sumberdaya manusia desa ini memiliki penduduk total 8276 jiwa yang terdiri dari laki-laki 4241 jiwa dan wanita 4035 jiwa. Pekerjaan yang penduduk mayoritas sekitar $70 \%$ adalah buruh harian lepas (kuli bangunan, buruh tani) dengan upah yang minim dan hanya 500 orang yang punya lahan dan sawah. Pemanfaatan sumber daya masih belum maksimal dimana penduduk mengolah sumber daya alam berupa tanaman yang memiki stok berlimpah di pasar sehingga harganya relatif murah, sehingga berdampak kesejahteraan masyarakat menjadi tidak tinggi. Meningkatkan kesejahteraan masyarakan merupakan hal yang perlu terus dilakukan sehingga dirasa perlu memperkenalkan kepada masyarakat tanaman baru yang dapat menambah penghasilan yang memiliki cara menanam yang mudah, dan tidak membutuhkan waktu banyak dalam merawatnya, cocok dengan kondisi masyarakat dan alam di Desa Gandatapa sehingga dapat meningkatan kesejahteraan masyarakat.

Salah satu upaya mangatasi kesejahteraan masyarakat dengan cara memperkenalkan tanaman Pepaya california kepada masyarakat dengan memanfaatkan lahan kosong, untuk dikembangkan sebagai pengembangan usaha yang cukup mudah dan dapat menghasilkan tambahan penghasilan bagi keluarga tanpa meninggalkan pekerjaan saat ini. Banyak sekali lahan 
kosong yang belum ditanami (utamanya milik perangkat desa) yang dapat dimanfaatkan untuk menanam Pepaya california berkualitas tinggi.

Sesuatu yang baru pada umumnya akan menciptakan keraguan. Seperti halnya pengenalan tanaman Pepaya california kepada masyarakat desa Gandatapa, hambatan utamanya adalah keraguan tentang prospek tanaman Pepaya california. Untuk itu perlu sosialisasi dengan sejelas-jelasnya dan keberanian untuk mencoba/mempraktekan penanaman Pepaya california ini, apalagi hal tersebut telah mendapatkan dukungan dari aparat desa setempat. Momentum yang baik ini perlu dimanfaatkan semaksimal mungkin agar peluang bisnis penanaman Pepaya california ini tidak hilang, sekaligus dapat dijadikan pilot project.

Tanaman Pepaya california tidak sulit dalam menanamnya, harga bibit murah 2.000 per batang, waktu tanam sampai berbuah sangat singkat yaitu 7 bulan dan dapat berbuah selama 3 tahun, minim hama penyakit, modal tidak terlalu besar, permintaan pasar masih tinggi dan harga pasar 2000 - 2400 per kilogram, cocok dengan kondisi tanahnya, dapat memanfaatkan lahan kosong yang tak terpakai.

Permasalahan yang dihadapi masyarakat desa Gandatapa saat ini adalah Bagaimana meningkatkan kesejahteraan tanpa meninggalkan pekerjaan mereka saat ini dengan usaha yang mampu dilakukan oleh mayoritas masyarakat?

Tujuan iptek bagi masyarakat ini adalah memberikan penyuluhan tentang potensi keuntungan menanam Pepaya california kualitas unggulan, serta melatih cara menanam Pepaya california dengan benar kepada masyarakat (dalam hal ini prioritas pelatihan diutamakan para buruh tani).

Manfaat Iptek bagi Masyarakat adalah masyarakat dapat mendapat pengetahuan bisnis dan peluang bisnis tentang tanaman Pepaya california. Kedua, masyarakat dapat memanfaatkan lahan kosong untuk ditanami Pepaya california. Ketiga, masyarakat dapat meningkatkan kesejahteraan dengan menjual tanaman Pepaya california.

\section{METODE YANG DIGUNAKAN}

Untuk memperoleh tujuan dan manfaat yang diharapkan dari pengabdian masyarakat ini, maka pengabdian masyarakat ini menggunakan metode:

1. Penyuluhan. Metode penyuluhan digunakan untuk memberikan pemahaman tentang bisnis dan tata cara penanaman Pepaya california oleh dosen dan narasumber dengan tujuan agar para buruh tani bisa memahami dari segi bisnis dan teknik penanaman Pepaya california dengan baik. Kegiatan penyuluhan tidak hanya berisi pengetahuan semata, namun juga memberikan tutorial berupa file presentasi yang berisi tentang panduan teknis menanam Pepaya california, dengan harapan bila dibutuhkan file tersebut bisa dibuka atau dicetak. Pemasaran perlu juga diperhatikan, sehingga dalam penyuluhan juga dibahas tentang pihakpihak yang dapat menyalurkan hasil panen Pepaya california tersebut. Bahan-bahan yang disampaikan dalam penyuluhan adalah sebagai berikut:

a. Potensi Budidaya Pepaya Calina (California) oleh Tim Dosen Fakultas Ekonomi Universitas Muhammadiyah Purwokerto.

b. Peluang Bisnis Pohon Pepaya California oleh Tim Dosen Fakultas Ekonomi Universitas Muhammadiyah Purwokerto.

c. Tatacara Penanaman Pepaya Calofornia oleh Salimin Petani Pepaya Desa Banjarsari Wetan.

2. Praktek menanam. Praktek menanam merupakan langkah pelaksanaan dari penyuluhan. Para buruh tani dapat lebih memahami teori dengan adanya praktek tanam. Praktek tanam diawasi oleh Bapak Salimin yang telah berpengalaman, sehingga dapat dipastikan proses praktek dapat dilaksanakan dengan tepat.

\section{HASIL DAN PEMBAHASAN}

Ipteks bagi masyarakat ini dilaksanaka guna mendapatkan manfaat yaitu Para Buruh tani dapat mendapat pengetahuan bisnis dan peluang bisnis tentang tanaman Pepaya california, serta 
dapat memanfaatkan lahan kosong untuk ditanami Pepaya california. Hal ini dapat terlaksana berkat kerjasama dari berbagai pihak yaitu para perangkat desa, akademisi (dosen) FEB UMP dan narasumber Pak Salimin yang mau berbagi ilmu dan pengalaman suksesnya dalam menanam Pepaya california. Harapan kedepan, masyarakat buruh tani dapat meningkatkan kesejahteraan dengan memulai menanam Pepaya california yang sangat prospek ke depan.

Peserta penyuluhan yang hadir sebanyak 16 peserta, dengan berbagai usia. Bertempat di SD 1 Desa Gandatapa RW 4 Kecamata Sumbang. Jam pelaksanaan mulai jam 16.45 sampai 17.30 atau 45 menit. Media yang digunakan LCD, Pengeras Suara, dan berada di salah satu ruang kelas Sekolah Dasar. Pelaksanaan praktek dilaksanakan hari berikutnya pada lokasi desa Gandatapa, dilaksanakan selama kurang lebih 2 jam. Para buruh tani mendapatkan bantuan 500 bibit Pepaya california dan pupuk.

Prospek Pepaya California menurut (www.langkahbisnis.com, 2016) yang membahas tentang ilmu menanam Pepaya California serta cerita sukses dibalik usaha budidaya Pepaya California. Bahkan keuntungan sampai 30 juta sekali panennya per minggu dengan jumlah pohon Pepaya sebanyak 10.000 pohon`

Untuk dapat membudidayakan Pepaya California perlu mengetahui potensi keuntungan agar dapat mengevaluasi budidaya tersebut sesuai dengan yang diharapkan. Untuk itu langkahlangkah sebagai berikut perlu disiapkan sebelum melaksanakan budi daya Pepaya California.

1. Menyiapkan Lahan Untuk Ditanami. Lahan seluas 8 hentar dapat ditanam sebanyak 10.000 pohon Pepaya atau bisa juga 1.000-1.500 Pepaya per hektar (ha).

2. Membeli bibit dengan harga Rp. 2.000 pohon. Misalnya 500 pohon= Rp. $2.000 \times 500=$ Rp. 100.000

3. Selama 4 bulan pohon akan siap dipanen. Tiap pohon dapat menghasilkan 25 sampai $30 \mathrm{~kg}$ per pohon. Jadi jika terdapat 500 pohon maka dapat menghasilkan $=25 \times 500=12.500$ kilo sekali panen.

4. Biaya operasional rata-rata yang dianggarkan $=10 \%$ dari penjualan.

5. Mengurangkan penjualaan dengan biaya, untuk mendapatkan laba.

Tabel berikut ini akan menghitung budidaya Pepaya California untuk 500 pohon untuk sekali panen. 4 bulan dari masa tanam Pepaya mulai berbunga dan bulan ke-7 dan ke- 8 Pepaya mulai berbuah dan dapat dipanen tiap minggunya.

Tabel 1. Ilustrasi Menanam Pepaya California

\begin{tabular}{|c|l|c|r|r|}
\hline NO & \multicolumn{1}{|c|}{ KEGIATAN } & \multirow{2}{*}{ SATUAN } & $\begin{array}{c}\text { HARGA } \\
\text { SATUAN (Rp) }\end{array}$ & JUMLAH (Rp) \\
\hline 1 & Penanaman pohon 500 pohon & Buah & 2.000 & 1.000 .000 \\
\hline 2 & Panen 500 pohon & Kg/ Pohon & 25 & 12.500 \\
\hline 3 & Harga jual per kg & Rp/ Kg & 3.500 & 43.750 .000 \\
\hline 4 & Biaya Operasi & Rp/ Pohon & 2.000 & 1.000 .000 \\
\hline 5 & Laba usaha & Rp & & 41.750 .000 \\
\hline 6 & Profitabilitas & $\%$ & & $4.175,00$ \\
\hline
\end{tabular}

Sumber: www`langkahbisnis.com, diolah 2016.

Profitabilitas merupakan kemampuan suatu perusahaan untuk mendapatkan laba (keuntungan) dalam suatu periode tertentu. Profitabilitas dihitung dengan rumus: laba/investasi)x $100 \%$.

Demikian hasil yang cukup fantastis dan menarik untuk dilaksanakan. Pohon Pepaya dapat berbuah kurang lebih selama 4 tahun. Pemasarannya pun mudah karena dapat dikirim ke pasar-pasar tradisional maupun modern yang terdekat. Mari memanfaatkan lahan yang tanah marginal yang tidak produktif menjadi tanah produktif. 
Meskipun telah berjalan dengan relatif baik namun terdapat beberapa kendala yang dihadapi. Meskipun kendala ini sulit dihindari, namun sebaiknya perlu ditingkatkan persiapan sebelum kegiatan pengabdian dilaksanakan agar lebih efektif dan efisien. Kendala tersebut adalah sebagai berikut:

1. Waktu untuk berkumpul dalam acara penyuluhan dan praktek sangat sulit ditentukan.

2. Waktu penyuluhan menjadi kurang optimal, karena hanya berkisar paling efektif 45 , menit termasuk tanya jawab.

3. Tidak ada pendampingan setelah pelatihan. Hal ini akan memperbesar potensi kegagalan program.

4. Sebaiknya peserta adalah berusia produktif, sehingga dapat memperbesar tingkat keberhasilan program.

Kendala penyuluhan diatas dapat diatasi dengan langkah-langkah sebagai berikut:

1. Memastikan waktu yang tepat, misalnya dihari libur.

2. Melakukan pendaftaran dan memberikan form kesediaan hadir.

3. Memberikan Uang honor kehadiran pagi peserta.

4. Lokasi penyuluhan dan praktek sebaiknya berdekatan agar tidak membutuhkan waktu lama untuk praktek.

5. Menseleksi peserta yang benar-benar berminat mengikuti program.

6. Mengadakan pendampingan selama periode yang dibutuhkan.

7. Melakukan kontrak sosial jika dimungkinkan agar program benar-benar berjalan dengan baik.

\section{KESIMPULAN DAN SARAN}

Pelaksanaan penyuluhan dan praktik Penanaman Pepaya California dengan Memanfaatkan Lahan Kosong Untuk Meningkatkan Kesejahteraan Masyarakat Khususnya Buruh Tani di desa Gandatapa, Kecamatan Sumbang, Kabupaten Banyumas telah berjalan dengan baik. Kunci keberhasilan terletak pada koordinasi dari berbagai pihak yang utama yaitu: perguruan tinggi, perangkat desa, dan narasumber.

Agar sebuah program dapat berjalan dengan baik dan kontinu sebaiknya ada anggaran yang lebih besar, perlu pendampingan, dan dukungan dari masyarakat yang luas, serta perlu adanya kontrak sosial, agar keberlanjutan program dapat terus berjalan.

\section{DAFTAR PUSTAKA}

Survei. (2016). Deskripsi $\backslash$ Desa Gandatapa Kecamatan Sumbang . Purwokerto: -.

www.langkahbisnis.com. (2016, Juli 12). Bisnis Cepat Kaya dari Budidaya Pepaya Calina (Pepaya California). Retrieved from http://www.langkahbisnis.com/bisnis-cepat-kayadari-budidaya-pepaya-calina/ 